German languages

Германські мови
ISSN: 2411-6181(on-line); ISSN: 2311-9896 (print)

Current issues of social studies and history of medicine. Joint Ukrainian -Romanian scientific journal, 2021, №:1(29), P. 57-60 UDK 94(477):323.1.

DOI 10.24061/2411-6181.1.2021.242

\author{
ЛЕКСИЧНА СЕМАНТИКА ДІССЛІВ НА \\ ПОЗНАЧЕННЯ ПРОЯВУ СУПЕРЕЧКИ В \\ АНГЛІЙСЬКІЙ МОВІ \\ Наталія СКРИЦЬКА, Тетяна НИКИФОРУК, \\ Буковинський державний медичний університет, \\ fedorkiv017@ukr.net
}

\title{
LEXICAL SEMANTICS OF THE VERBS DENOTING DEBATE IN ENGLISH
}

Natalya SKRYTSKA, Tetyana NYKYFORUK,

Bukovinian State Medical University,

ORCID 0000-0002-1498-4747

RESEARCHER ID: S - 7000-2016; ORCID ID:0000-0001-5365-5578

Наталия Скрыцкая, Татьяна Никифорук Лексическая семантика глаголов для обозначения проявления споров в английском языке. Семантическое значение глаголов для обозначения споров обосновывается культурой языка, привычками и традициями людей. Анализ глаголов для обозначения споров базируется на формализованном методе лексико-семантического анализа. Этот метод исследует семы, объединены в лексические единицы, а также связи между ними. Актуальность исследования заключается в необходимости формирования новых сем, а также определения глаголов высшей и наивысшей степеней полисемии, изучения моносемантических рядов лексического значения глаголов для обозначения споров в английском языке. Целью статьи является исследование семантики глаголов для обозначения проявления споров в английском языке. Методы исследования: описательный, аналитический, методы анализа и синтеза. Выводы. В результате исследования определены лексические и семантические особенности глаголов для обозначения споров в английском языке.

Ключевые слова: глаголь споров, семы, лексемы, полисемия, моносемантические ряды, высшая и наивысшая степени обозначения глаголов, лексическое значение глаголов споров.

Problem statement and its connection with important scientific tasks. The lexical set of English verbs denoting debate comprises 40 language units. Similar to contrasted Ukrainian lexemes, English language units have also been subdivided into three groups: verbs with the highest degree of polysemy, verbs with the middle degree of polysemy, and monosemantic ones.

The urgency of the research is to study lexical semantics of the verbs denoting debate in English.

The aim of the article is to identify common and distinctive semantic and monosemantic characteristics of the language units denoting debate in English language understudy.

The first group of words denoting debate in English is represented by 5 lexical units possessing 8-6 meanings (to oppose, to argue, to fence, to struggle, to dispute)

The first in this group is the lexeme to oppose which possesses 8 meanings characterizing it as a verb indicating the process of opposing someone as an antagonist: 'to set as an opponent or adversary', 'to be in opposition'. The meaning of resistance is clearly obvious in the seme 'to act against or furnish resistance to; combat' which correlates this lexeme with the verb to dispute. The two verbs are also semantically close in the semes indicating opposition 'to set against, esp. for comparison or contrast' and 'to set (something) opposite something else, or to set (two things) so as to be opposite one another'. The word to oppose also indicates the state of unfriendliness, enmity, and animosity 'to be hostile or adverse to, as in opinion' as well as preventing, inhibiting and baffling - 'to hinder or obstruct'.
The analyzed lexeme reveals its semantics in the set phrase as opposed to defined as follows: 'as contrasted with'.

The language unit to argue is semantically close to the word to dispute in its meaning 'to participate in a formal debate'. The distinctive positive lexical feature of the analyzed verb is its ability to indicate discussing and clarifying the issue - 'to state the reasons for or against' and explaining, indicating - 'to maintain in reasoning', 'to show; indicate'. The indication to convincing and presenting support is obvious in the meaning 'to persuade or compel by reasoning'. In addition, the lexeme to argue is capable of forming set phrases revealing its semantics of debate: argue around and around - 'to argue (about something) in a circuitous, indirect fashion, without an end or satisfactory result', argue back - 'to respond angrily or rudely at an inappropriate or unwelcome time', argue out - 'to discuss opposing views, with the goal of resolving a dispute', argue the toss - 'to dispute something', arguing for the sake of arguing - 'continuing a disagreement solely out of obstinacy', can't argue with that - 'a phrase used when one cannot or does not want to dispute what another person has said or suggested"l.

The following semantics meanings: 'to engage in skilful or witty debate, repartee, etc.' and 'to evade a question or argument, esp. by quibbling over minor points' semantically refer the lexeme to fence to the semantic space of debate and unites it with the word to argue. The studied word is also used in the following positive meanings: 'to construct a fence on or around (a piece of land, etc.)', 'to close (in) or separate (off) with or as if with a fence',

\footnotetext{
${ }^{1}$ Oxford Learner's Dictionary. URL: https://www.oxfordlearnersdictionaries.com/ (date 30.03. 2021) [in English].
} 
'archaic to ward off or keep out'. The negative meanings of the lexeme include: 'to fight using swords or foils', 'to receive stolen property'.

The meaning of arguing and competing is characteristic to the verb to struggle - 'to compete or argue with somebody/something, especially in order to get something'. Other meanings of the lexeme describe it as a verb of fighting, wrestling: 'to fight against somebody/something in order to prevent a bad situation or result', 'to fight somebody or try to get away from them'. The analyzed word also denotes striving and attempting - 'to try very hard to do something when it is difficult or when there are a lot of problems' and toiling - 'to move somewhere or do something with difficulty'. The lexical unit also reveals its semantics in the set phrase to struggle against someone or something - 'to strive or battle against someone or something, ${ }^{2}$.

The word to dispute possesses six meanings which describe it as the verb of arguing, debating 'to engage in argument or debate', 'to argue or debate about', 'to argue against', 'call in question', quarreling 'to argue vehemently; quarrel', 'to quarrel or fight about; contest' and opposing 'to strive against; oppose'. Thus, the verb is semantically close to all lexemes with the highest level of polysemy - to oppose, to argue, to fence, to struggle. In addition, the investigated language unit has the ability to form phrases: dispute something with someone - 'to argue with someone about something, such as an amount of money'.

The second group of lexemes denoting debate in English contains 26 verbs possessing 5-2 meanings and it represents the largest group in our investigation. It is composed of such lexical units as: to debate, to wrangle, to disagree, to clash, to discuss, to contend, to contradict, to withstand, to contest, to question, to quarrel, to collide, to bandy, to resist, to defy, to fend, to bicker, to agitate, to counter, to belie, to confute, to dissent, to controvert, to quibble, to thwart, to brawl.

The language units to debate, to wrangle, to disagree, to clash and to discuss are characterized by 5 meanings. The verbs to debate and to wrangle share the meaning of being involved in argument 'to engage in argument or discussion'. At the same time the words to debate and to clash coincide in the meaning 'to dispute or disagree about'. The meaning 'to argue or discuss (a question, issue, or the like), as in an assembly' semantically unites the verbs to debate and to discuss. The distinctive features of the word to debate are 'to participate in a formal debate' and 'to engage in formal argumentation with', 'to deliberate; consider'. In addition to above-mentioned features, the analyzed verb forms a phrase that allows to deeper disclose its semantics: debate on something - 'to hold a long and disciplined discussion on a particular subject' ${ }^{3}$.

The word to wrangle is characterized mainly by negative semantics defined as 'to argue or dispute, esp. in a noisy or angry manner', 'to argue or dispute', 'to obtain, often by badgering or scheming; wangle' containing the indications of altercation, sharp disagreement and bickering. The only positive seme of the analyzed verb denotes tending the cattle 'to tend or round up (cattle, horses, or other livestock)'. Moreover, the semantics of debate is revealed in the set phrase denoting squabbling: wrangle for an ass's shadow - 'to argue over trivial matters'
The semantics of conflicting actions is the common feature of the language units to disagree and to clash. The main meaning of the verb to disagree is 'to dissent in opinion (from another person) or dispute (about an idea, fact, etc.)' which reveals its semantics of holding different opinions. In addition to the meaning of conflict, the analyzed language unit denotes the failure to correspond to something. The negative meaning of being not suitable or satisfactory is revealed in the seme 'to be unacceptable (to) or unfavourable (for); be incompatible (with)'. The word is also characterized by its individual semantic feature 'to be opposed (to) in principle'. The analyzed lexeme discloses its semantics in the set expression agree to disagree - 'of two parties, to mutually accept that they simply do not (and will not) share the same view on a particular issue, in the interest of moving past the issue or avoiding further confrontation' which is used to denote the way of resolving a conflict.

The language unit to clash is mostly characterized by negative semantics revealed in its two meanings: 'to conflict; disagree', 'to engage in a physical conflict or contest (often fol. by with)'. The physical actions performed with a certain sound effect are expressed in the meanings 'to strike or collide with a loud, harsh, usu. metallic noise' and 'to strike with a loud, harsh, usu. metallic noise'. The negative quality of the color is disclosed in the meaning '(of juxtaposed colors) to be offensive to the eye'.

The word to discuss is characterized by positive semantics denoting the process of considering, deliberating: 'to speak with another or others about; talk over', 'to examine or consider (a subject) in speech or writing'. The process of human communication is expressed in the meaning 'to speak with another or others about something'. The lexeme also has specific lexical meaning of considering something in speaking or in the written form: 'to examine or consider a subject in speech or writing'. The positive semantic meaning 'to come to an agreement as a result of a discussion' indicates the way of overcoming various conflicts and concurring.

Eleven lexemes to contend, to contradict, to withstand, to contest, to question, to quarrel, to collide, to bandy, to resist, to defy and to fend (4 meanings) are characterized by both common and distinctive features. The verbs to contend, to contest and to defy are united by their common semantics denoting fight and struggle against smb. or smth.

The ability to form phrases is the characteristic feature of the language units to contend, to contradict, to withstand, to contest, to question, to quarrel, to collide and to bandy. Contend against someone or something - 'to fight or compete against someone or something' and contend with a problem 'to put up with a difficulty; to struggle with the problems caused by someone or something'; be no contest - 'used to say that one side in a competition is so much stronger or better than the other that it is sure to win easily'; to call in or into question - 'to dispute; challenge' and 'to cast doubt upon; question'; to quarrel out - 'to engage in a dispute or argument over some issue'; to quarrel with (smth.) - 'to disagree with, argue against, or complain about something'; bandy words (with smb.) - 'to argue with somebody or speak rudely to them'; to collide with someone or something - 'to crash with or bump into someone or something ${ }^{4}$.

The distinctive feature of the lexeme to contend is its ability to be used in negative and positive meanings: 'to struggle in rivalry, battle, etc; vie' and 'to argue earnestly;

\footnotetext{
${ }^{2}$ Ibidem.

${ }^{3}$ Ibidem.

${ }^{4}$ Longman Dictionary of Contemporary English for advanced leaners, $6^{\text {th }}$ Edition. URL: www.Idoceonline.com (date: 14.04.2021) [in English].
} 
debate', '(tr; may take a clause as object) to assert or maintain'.

The lexical unit to contradict is characterized only by negative semantics which unites it with the language units to withstand, to defy and to resist in the seme indicating the process of opposing someone: 'to assert the contrary or opposite of; to act or make efforts in opposition'. The verb under study also possesses the meaning of verbal differing or disproving: 'to speak contrary to the assertions of' and 'to imply a denial of'.

Apart from the meaning of opposing and resisting, the verb to withstand is characterized by the positive seme indicating endurance: 'to bear; tolerate the effects of'.

In addition to its semantics of opposing 'to withstand, strive against, or oppose', 'to withstand the action or effect of' and 'to act or make efforts in opposition', the word to resist is characterized by its semantic feature indicating restraining from something: 'to refrain or abstain from, esp. with difficulty'.

The language unit to defy has the specific meaning referring it to the military sphere - 'to invite to do battle or combat'. The characteristic feature of the verb is its negative semantic indication to instigating negative feelings and conflicts: 'to challenge or provoke (someone to do something judged to be impossible); dare'. It also has a positive semantics denoting the way of avoiding conflicts 'to elude, esp in a baffling way".

The lexical meaning 'to challenge; dispute' indicating challenging and disputing unites the words to contest and to question. The distinctive feature of the verb to contest is its indication of instructions on how to resolve the conflict through both peaceful and military action: 'to struggle or fight for, as in battle'; 'to dispute'; 'to call in question; challenge'; 'to contend'.

The lexeme to question possesses its individual semantics of interrogating which is obvious in its two meanings: 'to ask questions of; interrogate', 'to ask; inquire'. It also possesses an indication of doubting: 'to make a question of; doubt'.

The language units to quarrel and to bandy share the semantic meanings of the quarrel 'to disagree angrily; squabble; wrangle', 'to exchange (words) in a heated or hostile manner'. Both lexemes have their individual distinctive features. The verb to quarrel is characterized by the meaning denoting terminating the relationship with other people - 'to end a friendship as a result of a disagreement; fall out' as well as denouncing - 'to make a complaint; find fault".

The verb to bandy contains the semantics of fighting and is defined as: 'to give and receive (blows)'. The language unit is also used to denote human actions and manners of communicating: '(often foll by about) to circulate (a name, rumour, etc)', 'to throw or strike to and fro; toss about'.

The word to collide is characterized by the individual semantics denoting 'to clash; conflict'. It also indicates various physical activities: 'to cause to collide' and 'to strike one another or one against the other with a forceful impact; crash'. The verb to fend is characterized by positive semantics denoting defending, fighting for the preservation of something, resisting 'to ward off (often fol. by off)', 'to defend', 'to resist or make defense' and 'to provide; manage; shift'.

The verbs to agitate, to bicker, to counter, to belie, to confute possess three meanings. The lexemes in this subgroup share common lexical features as well as are characterized by their distinct semantic peculiarities

The words to bicker, to counter, and to belie are semantically close in their meaning 'to oppose; to set (something) opposite something else, or to set (two things) so as to be opposite one another'.

The word to bicker is characterized by the individual semantics and has the negative meaning 'to engage in peevish argument; wrangle'. This meaning is also enhanced by the set phrase bicker about (something) - 'to argue or squabble with someone about something'. In addition, the studied language unit is also used in the positive meanings 'to run or flow rapidly' and 'to flicker; glitter' denoting various parameters of physical phenomena. The meaning of opposition is characteristic to the lexeme to counter which is defined as 'to move or act in opposition to; oppose'. The semes of responding in retaliation 'to offer in response' and 'to meet or return ( $a$ blow) by another blow' also describe the verb under study. The lexeme to belie is used in the meaning of contradicting and misrepresenting the information 'to show to be false; contradict', 'to give a false impression of; misrepresent'. The negative meaning of deceiving also describes the studied verb 'to be false to or disappoint'.

The language units to agitate and to confute share the semantics 'to participate in a formal debate'. The verb to agitate expresses disturbing and troubling someone used in the meanings 'to cause to move with violence or sudden force' and 'to upset; disturb'. The language unit under study is also used in the positive meaning 'to arouse interest in (a cause, for example) by use of the written or spoken word; discuss or debate'. The verb to confute possesses the meanings indicating disproving and refuting 'to prove to be false, invalid, or defective; disprove', 'to prove (a person) to be wrong by argument or proof'. The language unit also denotes the process of confusing 'to bring to naught; confound'

Five lexemes to dissent, to controvert, to quibble, to thwart and to brawl have two meanings.

The verb to dissent possesses its specific semantics denoting disaccording 'to differ in sentiment or opinion, esp. from the majority (often fol. by from)' as well as rebuffing 'to reject the doctrines or authority of an established church ${ }^{6}$.

The language units to controvert, to quibble and to thwart coincide in the meaning of 'to oppose; to set (smth.) opposite something else, or to set (two things) so as to be opposite one another' indicating oppose, resist and objection.

However, they also have their specific semantic features. Thus, the language unit to controvert also denotes refuting and denying 'to deny, refute, or oppose (some argument or opinion)' while the verb to thwart is characterized by the semantics of preventing and frustrating 'to oppose successfully or prevent; frustrate'. The lexeme to quibble expresses disagreement over minor issues 'to argue or complain about trivial matters; bicker, carp, or cavil'. The meaning of eluding from direct answers also characterizes the studied word 'to use evasive or ambiguous language; equivocate'. In addition, the language unit to quibble is used in the set expression quibble over (something) with (someone) - 'to argue, dispute, or contend with someone over or about something, especially that which is trivial or petty'.

The verb to brawl has negative connotation denoting fighting 'to fight or quarrel angrily and noisily; wrangle'. It is also characterized by the positive semantics denoting physical parameters of sound 'to make a bubbling or roaring noise, as water flowing over a rocky bed'. The language unit to thwart indicates movement 'to be or move across'.

The vocabulary denoting debate in the English language

\footnotetext{
5 Ibidem.

${ }^{6}$ Ibidem.
} 
is composed of 9 monosemantic verbs (to altercate, to canvass, to deliberate, to squabble, to repugn, to discord, to disaccord, to recalcitrarte and to feud $)^{7}$.

To altercate, to canvass, to deliberate and to squabble form the semantic microsystem with the following meaning: 'to engage in argument or discussion; to argue or discuss' which expresses a noise argument, heated discussion, debate, wrangle etc.

The language unit to discord semantically relates with the lexeme to disaccord in the meaning of 'to dispute or disagree about'.

Other verbs in this group do not share common semantic features. The lexeme to feud reveals extremely negative semantics 'to carry on or perpetuate a bitter quarrel or state of enmity; to continuously argue or fight with someone about someone or something'. The verb to repugn indicates expressing vigorous opposition 'to oppose or conflict (with)', the semantics of the word to recalcitrate contains indications of a high degree of disagreement and disorder 'show strong objection or repugnance; manifest vigorous opposition or resistance; be obstinately disobedient'.

Our research has shown that each word is individual, but at the same time 6 monosemantic lexemes are interrelated in their meanings, forming the chain of direct and indirect connections.

The results of the analysis of the verbs denoting debate in English are represented in Table 3.2 manifesting the quantitative ratio and percentage of the singled out groups of verbs.

Lexical stock of the language units denoting debate in English

Table 1.1.

\begin{tabular}{|c|l|c|c|}
\hline № & \multicolumn{1}{|c|}{ Group of verbs } & Quantity & Percentage \\
\hline 1 & Verbs with the highest degree of polysemy & 5 & $12,5 \%$ \\
\hline 2 & Verbs with the middle degree of polysemy & 26 & $65 \%$ \\
\hline 3 & Monosemantic verbs & 9 & $22,5 \%$ \\
\hline & Total & $\mathbf{4 0}$ & $\mathbf{1 0 0 \%}$ \\
\hline
\end{tabular}

The data of the table prove that the verbs with the middle degree of polysemy comprise the largest group in the research sample making up $65 \%$ of all selected English language units. The group of monosemantic lexemes denoting debate is represented by $22,5 \%$ of lexemes while the group of verbs with the highest degree of polysemy is the least represented one and comprises $12,5 \%$ of the total sample.

Conclusion. Individual characteristics of the verbs denoting debate in English include:

a) different semantic composition of the analyzed lexemes in the contrasted languages;

b) overwhelming the negative meanings in the English language.

c) different ratio of lexemes according to the degree of polysemy.

The relation of the lexical and semantic composition of the comparable words is represented by a matrix in which the lexical semantics of the studied verbs is revealed, their relations and the place in the language system, etc.

Наталія Скрицька, Тетяна Никифорук. Лексична семантика дісслів на позначення прояву суперечки в англійській мові. Лексичне значення дієслів на позначення прояву суперечки визначається культурою мови, звичками традиціями народу. Аналіз дієслів на позначення прояву суперечки грунтується на формалізованому методі лексикосемантичного аналізу. Даний метод досліджує семи, об'єднані в лексичні одиниці, i, відповідно, зв'язки між ними. Завдяки цьому описано сферу впливу людини на повсякденне життя та відносини між людьми.

Історіографія. Дослідженням лексичного значення дієслів на позначення прояву суперечки в англійській мові займаються такі зарубіжні вчені, як А. Круз, Девід Крістал, Г. Ліч, М. Мьорфі, Пітер Метью та інші.

За основу дослідження взято такі лексикографічні джерела: Cambridge Advanced Leaner's Dictionary, Longman Dictionary of Contemporary English for advanced leaners, $6^{\text {th }}$ Edition, Macmillan English Dictionary for Advanced Leaners, Mark Laster The Big Book of English Verbs $1^{\text {st }}$ Edition, Oxford Learner's Dictionary.

Актуальність даної проблематики зумовлена необхідністю аналізу формування нових сем, вищих та найвищих ступенів полісемії та утворення нових моносемантичних рядів в лексичному значенні дієслів на позначення прояву суперечки. Метою статті $є$ дослідження семантики дієслів на позначення прояву суперечки в англійській мові. Об'єктом дослідження послугували особливості лексичного значення дієслів на позначення прояву суперечки в англійській мові. Методи дослідження: описовий, аналітичний, методи аналізу і синтезу. Наукова новизна полягає у тому, що вивчення дієслів на позначення прояву суперечки із визначенням їхніх ступенів полісемії та дослідженням моносемантичних рядів ще не були предметом аналізу.

Висновки. У результаті дослідження визначено лексичне значення дієслів на позначення прояву суперечки в англійській мові, а також проаналізовано різних ступенів полісемії цих дієслів.

Ключові слова: дієслова суперечки, семи, лексеми, полісемія, моносемантичні ряди, вищий та найвищий ступені визначення дієслів, лексичне значення дієслів суперечки.

Скрицька Наталія - викладач кафедри суспільних наук та украйнознавства Буковинського державного медичного університету. Автор та співавтор монографії, понад 30 наукових робіт. Коло наукових інтересів: історія філософії, філософія мови, філософія культури.

Skrytska Natalya is a teacher of Department of Social Sciences and Ukrainian Studies of Bukovinian State Medical University. The author and coauthor of the monograph, above 30 scientific works. Research interests: history of philosophy, philosophy of language, philosophy of culture.

Тетяна Никифорук - кандидат філологічних наук, дочент кафедри суспільних наук та украӥнознавства Буковинського держсавного медичного університету. Автор понад 80 науково-методичних публікацій. Коло наукових інтересів: теорія віршознавства загалом та поетика віршованих творів С. Воробкевича, викладання украӥнської мови як іноземної.

Tetyana Nykyforuk - Candidate of Philology, Associate Professor of Departament of Social sciences and Ukrainian Studies in Bukovinian State Medical University; Author of over 80 scientific and methodological articles. Executive secretary of Ukrainian-Romanian scientific journal "Current Issues of Social Studies and History of Medicine". Scientific research interests: the creation of poetry and poetics of S. Vorobkevych's verses, teaching of Ukrainian language as a foreign language.

Received: 18.01 .2021

Advance Access Published: March, 2021

(C) N. Skrytska, T. Nykyforuk, 2021 